\title{
Single Input Single Output Two Level Isolated Dc-Dc Converter With Secondary Side Phase Shifting For Solar Applications
}

\author{
K.Girinath Babu ${ }^{1}$, J.Sivavara Prasad ${ }^{2}$, V.Vasudevan ${ }^{3}$ \\ ${ }^{1}$ Asst. Professor, EEE Department, Gurunanak Institute, Hyderabad \\ ${ }^{2}$ Professor, EEE Department, Lakireddy Bali Reddy College of Engineering, Mylavaram \\ ${ }^{3}$ Asst. Professor, Electrical Engineering, Annamalai University \\ E-mail: ${ }^{1}$ girinath99@gmail.com
}

\begin{abstract}
The isolated dc-dc converters with primary-side phase shifting (PPS) provides severely narrow softswitching range for main devices in the primary side leg of full bridge converter. The leakage inductance of the high frequency transformer should be large enough for providing the energy needed for soft switching operations and also the idling power loss due to circulating current in the converter legs under large phase-shift angle, which makes reduction of conversion efficiency and complicated in designing the parameters of transformer. Furthermore, the turn-off diode commutations in the output-side rectifier are performed by hard-switching mode. To overcome all these drawbacks, a secondary side phase shifting (SPS) technique has been developed for two-level isolated DC-DC converter. This scheme provides wider soft switching range and reduced power loss due to elimination of circulating current in the primary side of high frequency transformer. In addition, SPS control also provide no reverse recovery current in diodes and hence no power losses in the secondary rectifier circuit. The control switches operate under soft switching even under rated load and short circuit conditions.
\end{abstract}

Keywords: Single Input, Single output, Isolated DC-DC Converter, Switching losses. Zero voltage Switching (ZVS), Secondary Side phase shifting (SPS)

\section{Introduction}

In [1] \&[2] several active snubbers and in [2]\&[3] several passive snubbers, auxiliary and clamp circuits were proposed to resolve the issue concern the resetting of primary current of transformer to make ZCS of devices in the right leg of converter. The selected converters are very well adapted for no load and normal load, whereas at short circuit, they do not minimize freewheeling current and, therefore, turn-off and conduction losses occur. The clamp voltage is lower or equal than the output voltage, and thereby the commutation between the clamp and output rectifier is long, especially at highcurrent, high leakage inductance of the power transformer and low-output-voltage applications.
Several techniques have been developed to extend ZVS range to get better efficiency of full-bridge phase-shift controlled converters, [4]-[7].

A primary-side phase shifting is a typical and basic control scheme has been developed in [8], [9], this technique reduces electromagnetic interference. In addition, the pulse width modulation (PWM) zero-voltage switching $\mathrm{dc}-\mathrm{dc}$ converters with primary-side phase shifting have a severely narrow soft-switching range for main devices in the PS leg of FB inverter. The leakage inductance of the HF transformer should be large enough for providing the energy needed for soft switching operations, which makes reduction of conversion efficiency and complicated in designing the parameters of transformer. The idling power loss due to circulating current in the inverter legs under large phase-shift angle. This result, the converter efficiency of dc-dc converters severely decreases, in especially, for the light load power ratings [17] and [18]. Furthermore, the turn-off diode commutations in the output-side rectifier are performed by hard-switching mode, which operates with the voltage surges and thereby reduction of converter efficiency.

To overcome the limitations of PWM- ZVS dc-dc converters, secondary-side phase shifting has been considered and the related soft-switching dc- dc PWM converter circuits have been introduced for generation of power supplies. The first time secondary-side phase shifting scheme was introduced in [10], here the saturable inductors are used as the primary side-controlled devices. Even though some challenges still present, the PWM dc-dc secondary side phase shifting controlled converters are attractive because of simple structures and wide range of soft-switching operations. The effectiveness of secondary-side phase shifting schemes with active rectifiers is discussed over the past few years while number of other technical papers has discussed the PWM dcdc converters with primary side phase control. In [11], the idea of secondary side phase shifting scheme for a PWM ZVS dcdc converter, and indicated the fundamental principle along with theoretical analyses and fundamental experimental discussions are presented. The discussions and practical evaluations on voltage regulations and output power as well as the conversion efficiencies under the different load conditions are unclear. The secondary-side phase-shift control mechanism 
is proposed in [12]-[14], where the duty cycle of both secondary and primary active devices keeps 0.5 and the phaseshift angle between secondary and primary devices is selected as the freedom to control and regulate the output voltage.

In this research work, a secondary side phase shifting mechanism has been proposed. With the proposed secondaryside phase shifting control scheme, the freewheeling current is effectively eliminated and the voltage spikes on secondaryside devices are suppressed. The soft-switching $\mathrm{dc}-\mathrm{dc}$ converters with secondary-side phase shift can provide wide range of soft-switching conditions and effective minimization of power loss drawing from the circulating current in the primary-side of high frequency transformer. In addition, the secondary-side phase shifting PWM ZVS dc-dc converter is free with diode reverse recovery current and related power loss in the output side of rectifier, so, the RCD snubbers for rectifying diodes are eliminated.

The paper is divided into three sections. The introduction of paper is given in section 1. The modes of operation, realization of soft switching, design equations, and results of proposed single input single output two-level DCDC converter with SPS are presented in section 2 and 3. The conclusion of the paper is given in section 4 .

\section{ZVS ISOLATED DC-DC CONVERTER WITH SECONDARY SIDE PHASE SHIFTING:}
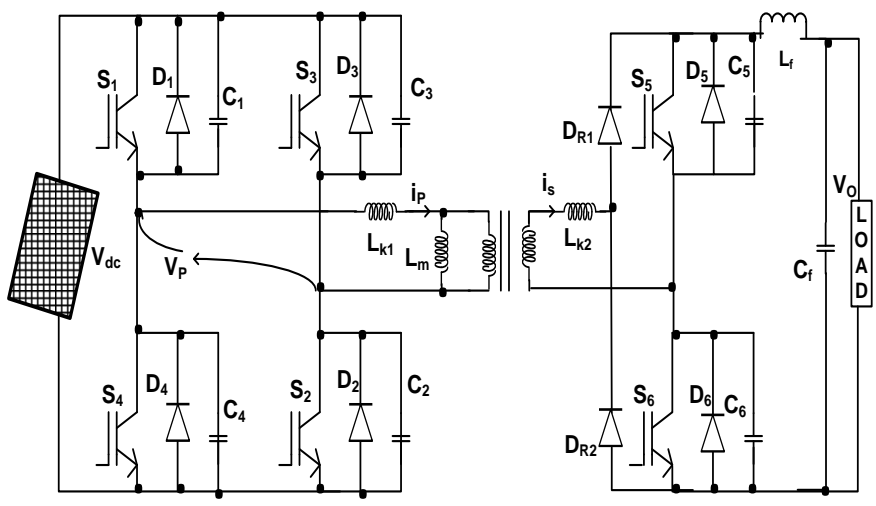

Figure 2.1: ZVS-PWM dc-dc converter with SPS active rectifier.

The figure 2.1 shows the circuit diagram of two level single input single output ZVS isolated DC-DC converter with secondary side phase shifting. The switches $\mathrm{S}_{1}-\mathrm{S}_{4}$ are the transformer primary switches and $S_{5} \& S_{6}$ are the bidirectional transformer secondary switches. The switches $S_{5}$ and $S_{6}$ operate in the phase shift manner with the primary side switches $S_{1}$ and $S_{3}$. The switches $S_{1}$ and $S_{3}$ are turned on complementarily for $180^{\circ}$ period.

The advantages of SPS scheme are:

(i) Wider soft switching range is possible due to load variations (ii) No idling power loss due to circulating current in the primary side

(iii) No additional components are required for achieving soft switching

(iv) The secondary side diodes are operating under ZVS for turn on/off transitions. So, the reverse recovery current in diode is eliminated.

(v) The dynamic response of a converter is faster due to load variations because of presence of secondary control scheme.

\section{Modes of operation:}

The figure 2.2 shows the operational waveforms of proposed converter. The figures 2.3 to 2.12 show the modes of operation of two level ZVS DC-DC converter with SPS for one cycle.

\section{Mode $1\left(\mathbf{t}_{0} \leq \mathbf{t}<\mathbf{t}_{1}\right)$ :}

During this mode, the switches $\mathrm{S}_{3}$ and $\mathrm{S}_{4}$ are turned off under ZVS. So, the capacitors $\mathrm{C}_{3}$ and $\mathrm{C}_{4}$ are starts charging whereas capacitors $C_{1}$ and $C_{2}$ are discharging through the current in primary winding of transformer. The switch $\mathrm{S}_{5}$ is still on along with diode $D_{5}$ and $D_{R 2}$ and majority of the current is transmitted through $\mathrm{D}_{5}$ and $\mathrm{D}_{\mathrm{R} 2}$ only, as shown in figure 2.3. The capacitors $\mathrm{C}_{1}$ and $\mathrm{C}_{2}$ are fully discharged to zero before time $t=t_{1}$. Hence its body diodes $D_{1}$ and $D_{2}$ are on. So, the switches $S_{1}$ and $S_{2}$ are ready to operate under ZVS at the end of time $t=t_{1}$.

The voltage across switches $\mathrm{S}_{1}-\mathrm{S}_{4}$ under this mode are,

$$
\begin{aligned}
& v_{\mathrm{C} 1}(\mathrm{t})=v_{\mathrm{C} 2}(\mathrm{t})=I_{p} \cdot Z_{1} \cdot \sin \left[w_{1}\left(\mathrm{t}-t_{0}\right)\right] \\
& v_{\mathrm{C} 3}(\mathrm{t})=v_{\mathrm{C} 4}(\mathrm{t})=V_{d c}-I_{P} \cdot Z_{1} \cdot \sin \left[w_{1}\left(\mathrm{t}-t_{0}\right)\right]
\end{aligned}
$$

Where $I_{p}$ represents the transformer primary current at $\mathrm{t}=\mathrm{t}_{0}, \mathrm{t}_{5}, \mathrm{t}_{10}$ in figure 2.2. Where $\mathrm{Z}_{1}=\frac{1}{W C_{1}}=\frac{1}{2 \pi f_{S} C_{r 1}}, \omega_{1}$ $=\frac{1}{2 L_{k p} C_{r 1}}, \mathrm{C}_{1}=\mathrm{C}_{\mathrm{r} 1}=\mathrm{C}_{2}=\mathrm{C}_{3}=\mathrm{C}_{4}, L_{k p}$ indicates the inductance referred to primary side of converter, $L_{m}$ is the magnetizing inductance and $\omega_{1}$ is the primary side angular resonant frequency.

$L_{k p}=L_{k 1}+N_{T}^{2} L_{k 2} \ll L_{m}$

\section{Mode $2\left(\mathbf{t}_{1} \leq \mathbf{t}<\mathbf{t}_{2}\right)$ :}

At time $\mathrm{t}=\mathrm{t}_{1}$, the switches $\mathrm{S}_{1}$ and $\mathrm{S}_{2}$ are turned on under ZVS. Due to leakage inductances in the transformer primary and secondary, the primary current is still not reached to zero. In this mode, the switch $\mathrm{S}_{5}$ is still on along with $\mathrm{D}_{5}$ and $D_{R 2}$ in the secondary side of transformer, as shown in figure 2.4 .

The value of primary current from mode 1 to mode 2

is

$i_{p}(\mathrm{t})=\frac{V_{d c}+N_{T} V_{0}}{L_{k p}}\left(t-t_{0}\right)$. 
Where $\mathrm{N}_{\mathrm{T}} \quad\left(=\mathrm{N}_{\mathrm{P}} / \mathrm{N}_{\mathrm{S}}\right)$ indicates turn ratio of transformer from primary to secondary.

The transition period $T_{c 1}$ for the switches $S_{1}-S_{4}$ can be determined from equations (2.1) and (2.2) for ZVS commutation as

$T_{c 1}=\frac{1}{W_{1}} \sin ^{-1}\left(\frac{V_{d c}}{Z_{1} I_{p}}\right) \leq t_{0-1}$

Where $t_{0-1}$ denotes the dead time of the switches $S_{1} / S_{4}$ and $S_{3} / S_{2}$.

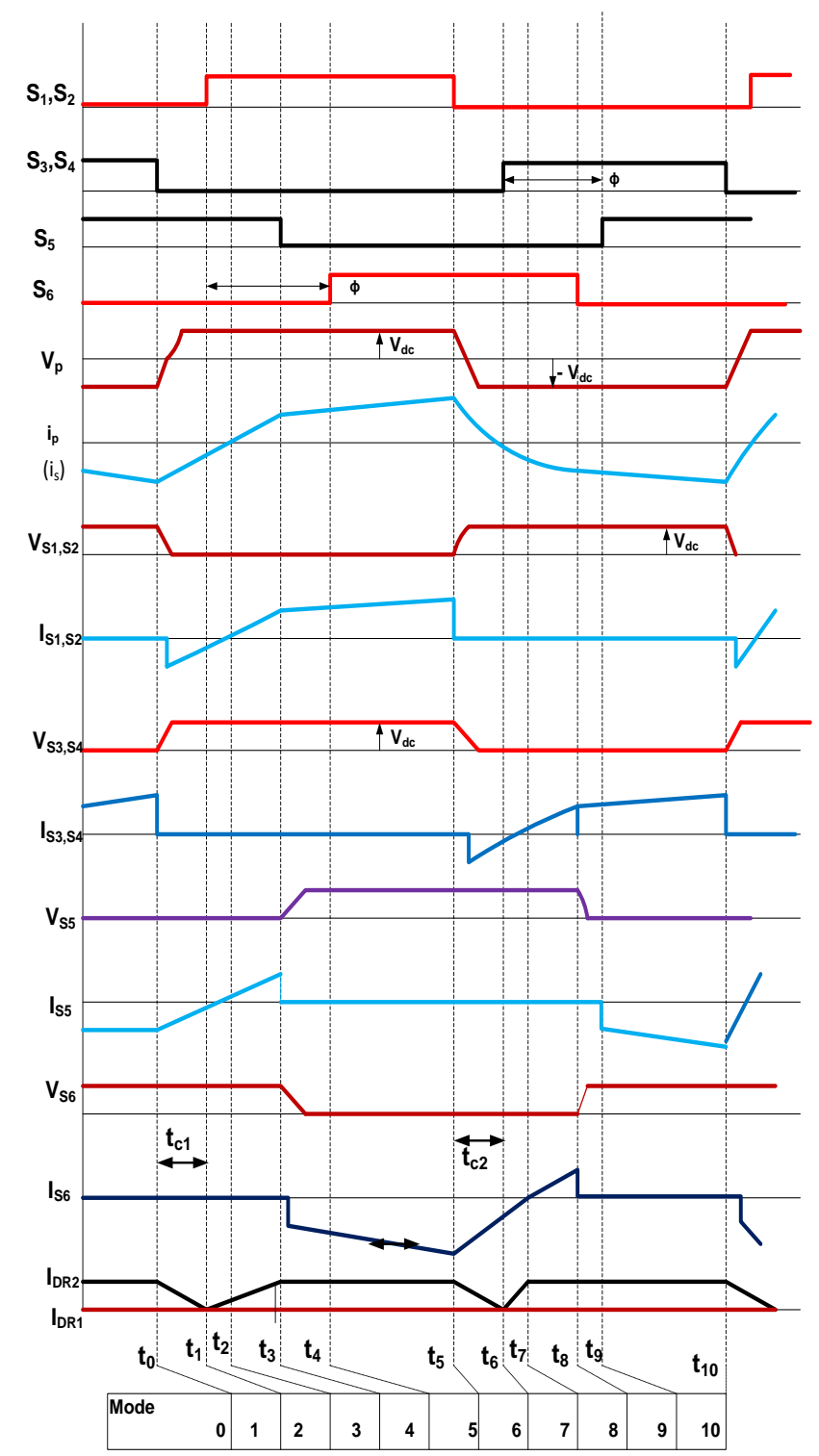

Figure 2.2: Relevant voltage and current waveforms of proposed DC-DC converter

\section{Mode $3\left(t_{2} \leq \mathbf{t}<\mathbf{t}_{3}\right)$ :}

At time $t=t_{2}$, the primary current in the circuit is reached to zero from negative direction and thereby the diode $D_{R 2}$ is turned off due to reversed biased condition and $D_{R 1}$ is turned on along with conducting switch $S_{5}$ due to forward biased condition. Here, the diode $\mathrm{D}_{\mathrm{R} 2}$ is off under ZCS and
$D_{R 1}$ is on under ZCS. In this case, the load is disconnected from the dc source and it is indicated in figure 2.5.

The current $i_{p}$ in this mode is,

$I_{p}(t)=\frac{V_{d c}}{L_{k p}}\left(t-t_{0}\right)$

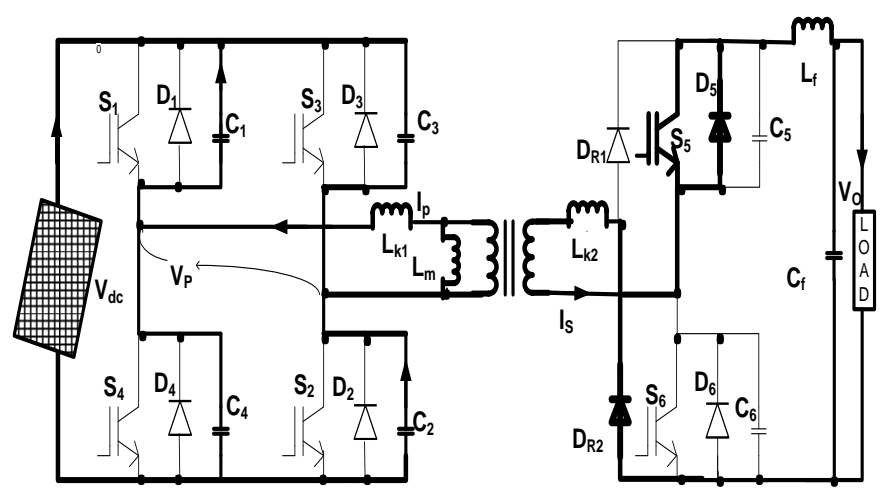

Figure 2.3: Equivalent circuit for mode ' 1 ' operation

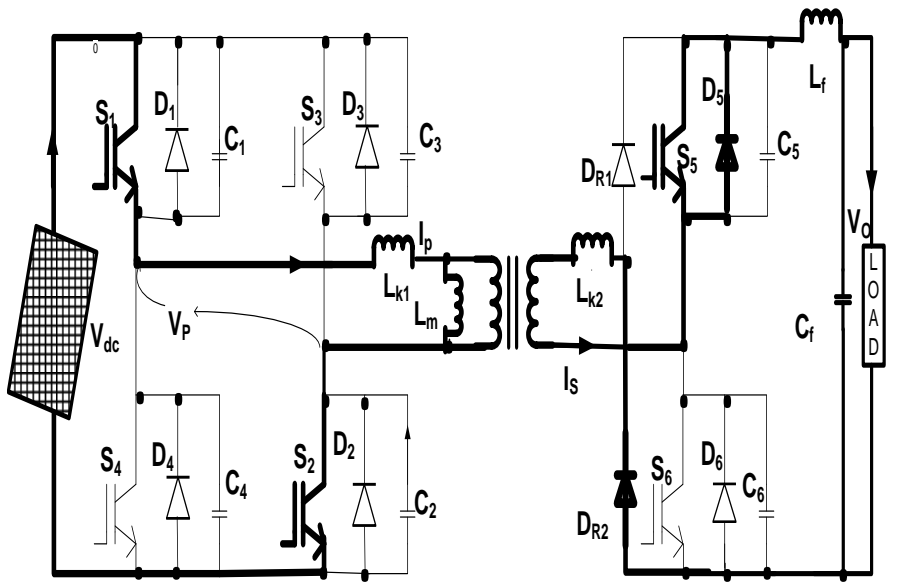

Figure 2.4: Equivalent circuit for mode '2' operation

\section{Mode $4\left(\mathbf{t}_{3} \leq \mathbf{t}<\mathbf{t}_{4}\right)$ :}

At time $\mathrm{t}=\mathrm{t}_{3}$, the switch $\mathrm{S}_{5}$ is turned off under ZVS. So, the capacitor $\mathrm{C}_{5}$ starts charging where as capacitor $\mathrm{C}_{6}$ starts discharging based on the direction of current in the secondary side of transformer. The primary side switches $S_{1}$ and $S_{2}$ are still on and the load receives power from source through secondary diode diode $\mathrm{D}_{\mathrm{R} 1}$ as indicated in figure 2.6. The capacitor $\mathrm{C}_{6}$ is completely discharged to zero before time $\mathrm{t}=\mathrm{t}_{4}$. Hence, the body diode of switch $\mathrm{S}_{6}$ is on and thereby the switch $S_{6}$ is ready to operate under ZVS at the end of time $t=t_{4}$.

The $\mathrm{S}_{5}$ and $\mathrm{S}_{6}$ switch voltages are

$$
\begin{aligned}
& v_{\mathrm{C} 5}(\mathrm{t})=I_{s} \cdot Z_{2} \cdot \sin \left[w_{2}\left(\mathrm{t}-t_{3}\right)\right] \\
& v_{\mathrm{C} 6}(\mathrm{t})=V_{o}-I_{s^{\prime}} \cdot Z_{2 \cdot} \cdot \sin \left[w_{2}\left(\mathrm{t}-t_{3}\right)\right]
\end{aligned}
$$

Where $I_{s}$ represents the transformer secondary current. Where $\mathrm{Z}_{2}=\frac{1}{W C_{r 2}}=\frac{1}{2 \pi f_{s} C_{r 2}}, \quad \omega_{2}=\frac{1}{2 L_{k s} C_{r 2}}, \mathrm{C}_{5}=\mathrm{C}_{\mathrm{r} 2}$ $=\mathrm{C}_{6}, L_{k s}$ indicates the inductances referred to secondary as, 


$$
\mathrm{L}_{\mathrm{ks}}=\mathrm{L}_{\mathrm{k} 2}+\frac{1}{N_{T}^{2}} \mathrm{~L}_{\mathrm{k} 1} \ll \mathrm{L}_{\mathrm{m}}
$$
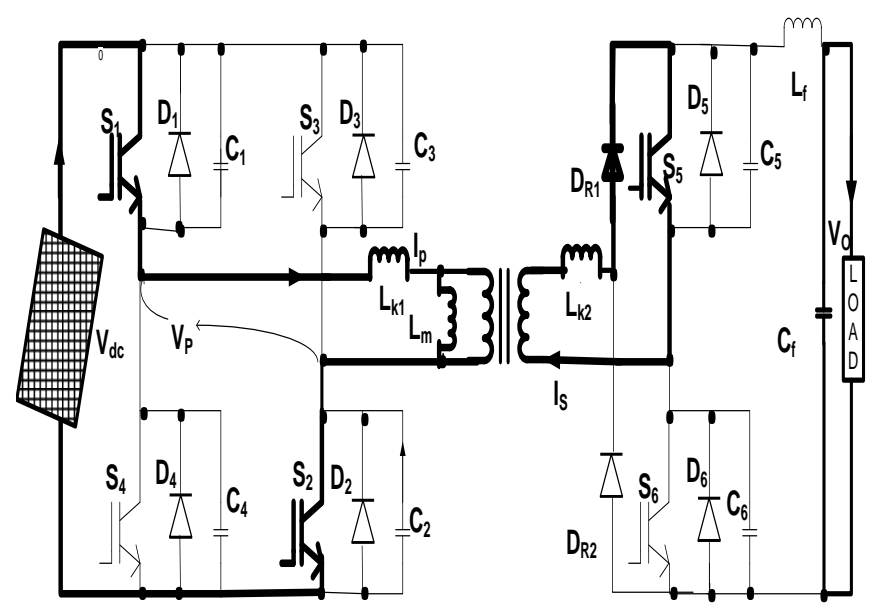

Figure 2.5: Equivalent circuit for mode '3' operation

The transition period $T_{c 2}$ for the switches $S_{5}$ and $S_{6}$ can be determined from equations (2.7) and (2.8) for ZVS commutation as

$$
T_{c 2}=\frac{1}{w_{2}} \sin ^{-1}\left(\frac{V_{0}}{Z_{2} I_{s}}\right) \leq t_{5-6}
$$

Where $t_{5-6}$ indicates the dead time for the switches $\mathrm{S}_{5}$ and $S_{6}$.

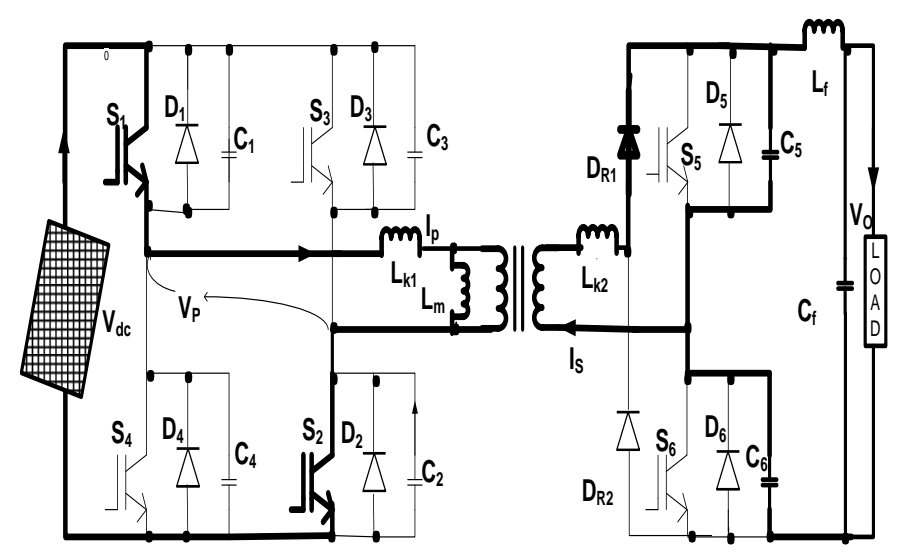

Figure 2.6: Equivalent circuit for mode '4' operation

\section{Mode $5\left(t_{4} \leq \mathbf{t}<t_{5}\right)$ :}

At time $\mathrm{t}=\mathrm{t}_{4}$, the control switch $\mathrm{S}_{6}$ is on under ZVS along with the conducting diode $\mathrm{D}_{\mathrm{R} 1}$ in the secondary side. The current in the circuit is flowing from zero to positive direction and load receives power from dc source through switches $S_{6}$ and $D_{R 1}$, as shown in figure 2.7 .

The current expression from mode 4 to mode 5 is

$i_{p}(t)=\frac{V_{d c}-N_{T} V_{0}}{L_{k p}}\left(t-t_{5}\right)$

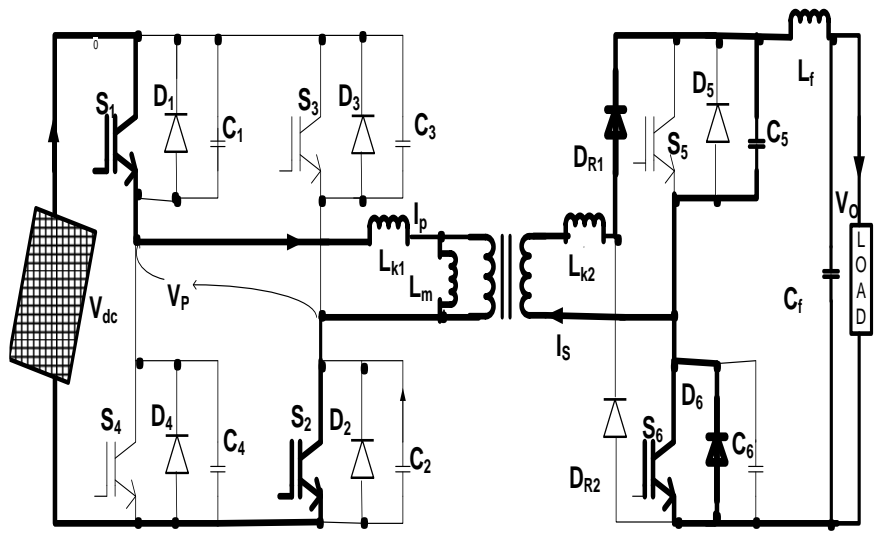

Figure 2.7: Equivalent circuit for mode '5' operation

Mode $6\left(t_{5} \leq t<t_{6}\right)$ :

At time $t=t_{5}$, the switches $S_{1}$ and $S_{4}$ are turned off under ZVS. So, the capacitors $C_{1}$ and $C_{2}$ are starts charging and capacitors $\mathrm{C}_{3}$ and $\mathrm{C}_{4}$ are starts discharging through current in the primary side of transformer. The idling power loss due to circulating current in the primary side can be reduced due to phase shift control switch $S_{6}$. The switch $S_{6}$, diodes $D_{6}$ and $D_{R 1}$ are operating in the secondary side and majority of the current flows through the diodes $\mathrm{D}_{6}$ and $\mathrm{D}_{\mathrm{R} 1}$ only. Before time $\mathrm{t}=\mathrm{t}_{6}$, the capacitors $\mathrm{C}_{3}$ and $\mathrm{C}_{4}$ are completely discharged to zero. Hence the body diodes of switches $\mathrm{S}_{3}$ and $\mathrm{S}_{4}$ are on and thereby the switches $\mathrm{S}_{3}$ and $\mathrm{S}_{4}$ are ready to operate under ZVS at the end of time $\mathrm{t}=\mathrm{t}_{6}$, as shown in figure 2.8 .

\section{Mode $7\left(\mathbf{t}_{6} \leq \mathbf{t}<\mathbf{t}_{7}\right)$ :}

At time $t=t_{6}$, the switches $S_{3}$ and $S_{4}$ are turned on under ZVS. Due to leakage inductances in the transformer, the current in the circuit cannot change suddenly from positive to negative. Therefore the diode $\mathrm{D}_{\mathrm{R} 1}$ is still on along with control switch $S_{6}$ and $D_{R 2}$ in the secondary side, as shown in figure 2.9.

\section{Mode $8\left(\mathbf{t}_{7} \leq \mathbf{t}<\mathbf{t}_{8}\right)$ :}

At time $\mathrm{t}=\mathrm{t}_{7}$, the current in the circuit is changed from positive to zero. Hence the diode $\mathrm{D}_{\mathrm{R} 1}$ is off under ZCS due to reversed biased condition and diode $\mathrm{D}_{\mathrm{R} 2}$ is on under ZCS due to forward biased condition with the conducting switch $\mathrm{S}_{6}$. In this mode, the load is disconnected from the dc source and it is shown in figure 2.10 . 


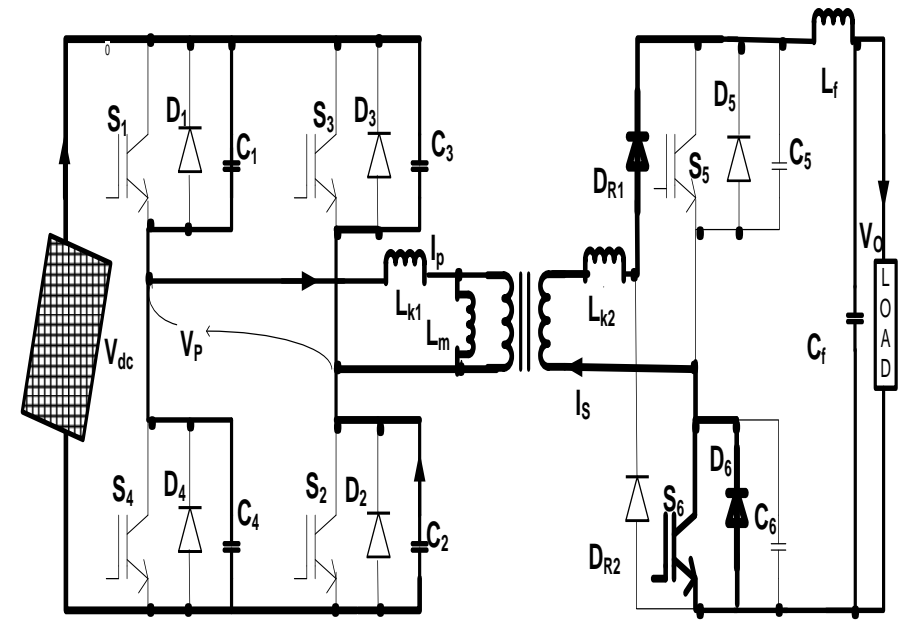

Figure 2.8: Equivalent circuit for mode '6' operation

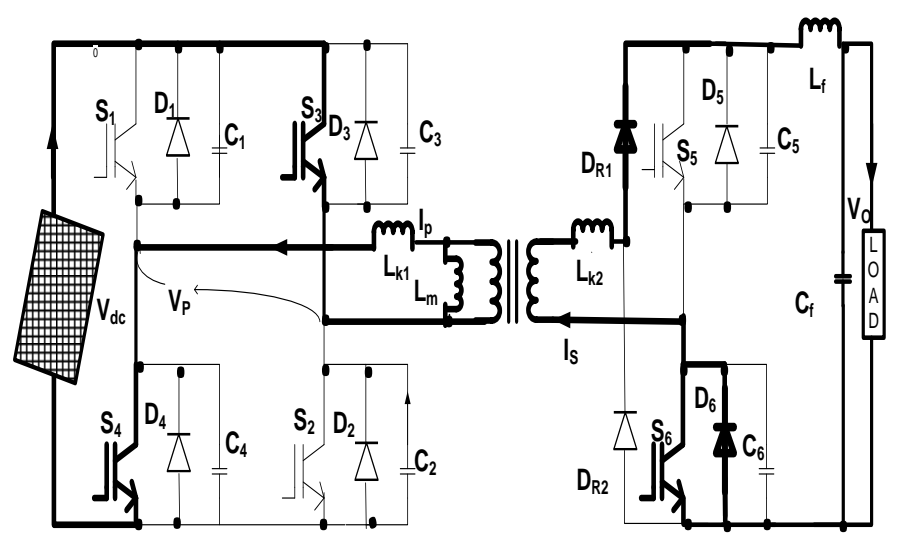

Figure 2.9: Equivalent circuit for mode '7' operation

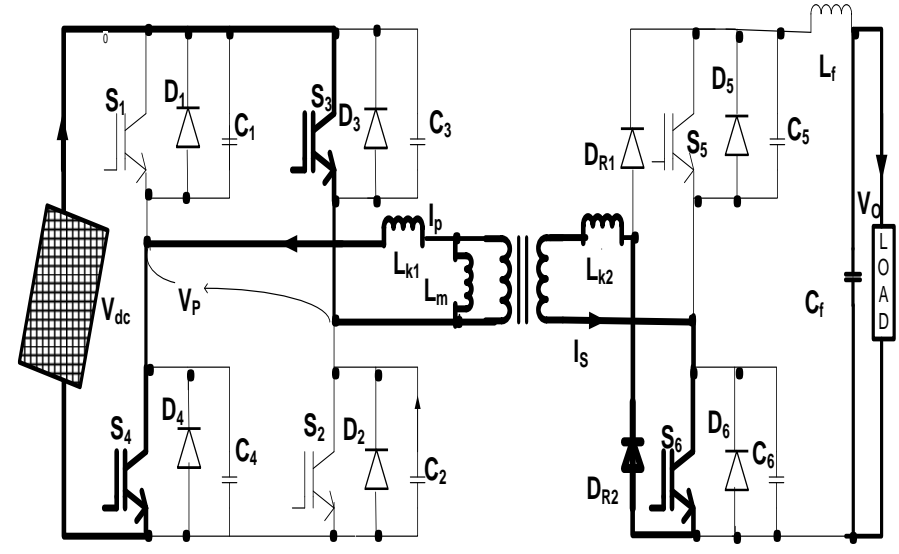

Figure 2.10: Equivalent circuit for mode '8' operation

Mode $9\left(\mathbf{t}_{8} \leq \mathbf{t}<\mathbf{t} 9\right)$ :

At time $\mathrm{t}=\mathrm{t}_{8}$, the switch $\mathrm{S}_{6}$ is turned off under ZVS. The capacitor $C_{6}$ starts charging whereas the capacitor $C_{5}$ starts discharging. The load receives power from source through the diode $D_{R 2}$ in the secondary side and the switches $\mathrm{S}_{3}$ and $\mathrm{S}_{4}$ in the primary side. Before time $\mathrm{t}=\mathrm{t}_{9}$, the capacitor $\mathrm{C}_{5}$ is fully discharged to zero and corresponding body diode of
$\mathrm{S}_{5}$ is on. Therefore the switch $\mathrm{S}_{5}$ is ready to operate under ZVS after time $\mathrm{t}=\mathrm{t}_{9}$, as shown in figure 2.11 .
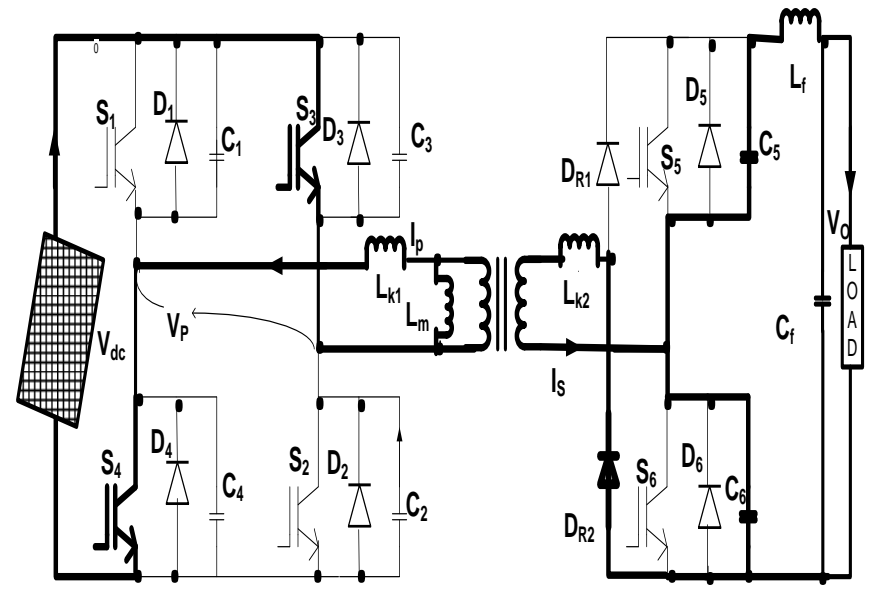

Figure 2.11: Equivalent circuit for mode '9' operation Mode $10\left(\mathbf{t}_{9} \leq \mathrm{t}<\mathbf{t}_{10}\right)$ :

At time $\mathrm{t}=\mathrm{t}_{9}$, the switch $\mathrm{S}_{5}$ is on under ZVS along with the conducting diode $D_{R 2}$. So, the current in the circuit is flowing from zero to negative direction through the primary switches $S_{3}$ and $S_{4}$ and the secondary side switches $D_{R 2}$ and $S_{5}$ as shown in figure 2.12 .
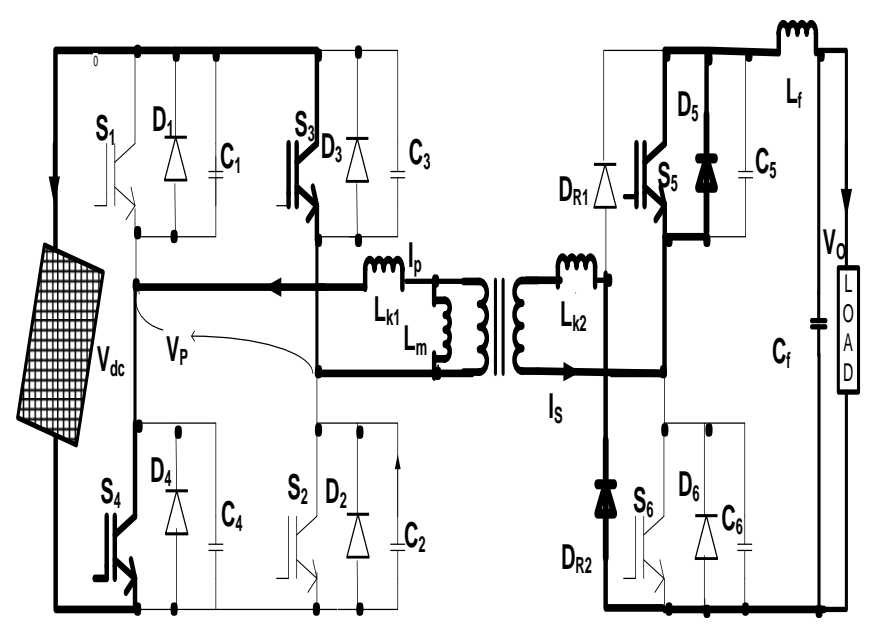

Figure 2.12: Equivalent circuit for mode '10' operation

\subsubsection{Realization of soft switching:}

As compared to primary side phase shifting scheme, the secondary side phase shifting scheme can reduce the circulating current in the primary side of inverter. Due to this feature, the soft switching is simple and wider.

The primary voltage and current waveform of primary side of inverter in PPS and SPS schemes are shown in figures 2.13 (a) and (b). The edge resonance in the lagging phase shift switches $S_{2}$ and $S_{3}$ are depends on the magnitude of circulating current. The ZVS operation is not possible in the phase shifted switches $S_{3}$ and $S_{2}$ during low output power. The SPS scheme does not provide any lagging phase shift in the 
primary side of inverter. Hence all the control switches in the primary side of transformer are under ZVS, hence

$\frac{L_{k p}^{2} * I_{p}^{2}}{2}>2 * V_{d c}^{2} * \mathrm{C}_{\mathrm{r} 1}$

$\mathrm{I}_{\mathrm{p}}$ denotes the magnitude of primary current and $\mathrm{C}_{1}=\mathrm{C}_{2}=\mathrm{C}_{3}=\mathrm{C}_{4}=\mathrm{C}_{\mathrm{r} 1}$ is the primary resonant capacitor.

In addition to (2.12), the equation (2.4) must be satisfied in the ZVS condition in the secondary side switches $\mathrm{S}_{5}$ and $\mathrm{S}_{6}$ are

$\frac{L_{k p}^{2} * I_{s}^{2}}{2}>\frac{\mathrm{C}_{\mathrm{r} 2} * V_{d c}^{2}}{N_{T}^{2}}$

$\mathrm{I}_{\mathrm{S}}$ denotes the magnitude of secondary current and $\mathrm{C}_{5}=\mathrm{C}_{6}=\mathrm{C}_{\mathrm{r} 2}$ is the secondary resonant capacitor

In addition to equation (2.13), the equation (2.10) must be satisfied in this case. The equations (2.12) - (2.13) and (2.4) - (2.10) shows that the soft switching range in the proposed converter depends on the load power. The soft switching is very critical in the light load conditions. In order to achieve wide range of ZVS in the light load conditions, an introduction of dead time control to SPS scheme is to be added.

The rectifying diodes $D_{R 1}$ and $D_{R 2}$ are turned-off under ZCS. These switches are operating under ZCS in the full load range. There are no parasitic ringing in ZCS turn-off commutating diodes $\mathrm{D}_{\mathrm{R} 1}$ and $\mathrm{D}_{\mathrm{R} 2}$. Hence no active and passive snubber for voltage clamping in the rectifying diodes are required. Therefore the switching power losses and conduction losses can be minimized in the secondary diodes $D_{R 1}$ and $D_{R 2}$.

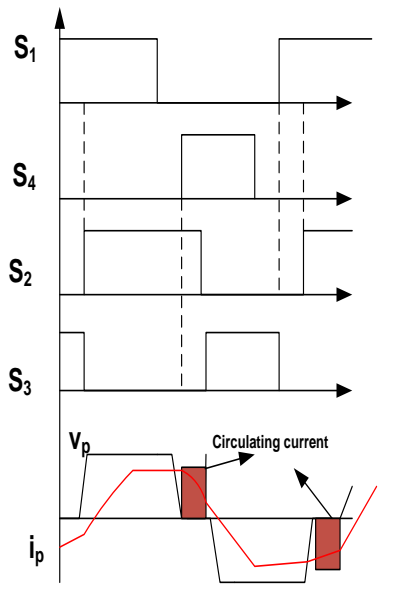

(a)

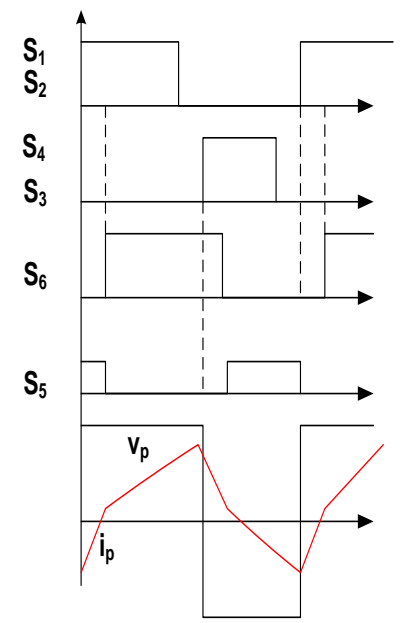

(b)
Figure 2.13: Phase shifting gate pulse patterns and waveforms in primary-side inverter: (a) PPS (b) SPS.

\subsubsection{Design equations:}

The converter design indicates the design of values for $\mathrm{C}_{1}, \mathrm{C}_{2}, \mathrm{C}_{3}, \mathrm{C}_{4}, \mathrm{C}_{5}, \mathrm{C}_{6}, \mathrm{~L}_{\mathrm{k} 1}, \mathrm{~L}_{\mathrm{k} 2}, \mathrm{~L}_{\mathrm{f}}$ and $\mathrm{C}_{\mathrm{f}}$.

The output inductor should be large enough to make the output current should be continuous throughout the switching period and leakage inductance of transformer must be small enough to make the less reset time.

The resonant capacitor $\mathrm{C}_{\mathrm{r} 1}\left(=\mathrm{C}_{1}=\mathrm{C}_{2}=\mathrm{C}_{3}=\mathrm{C}_{4}\right)$ must be selected in such a way that the minimum requirement for $\mathrm{ZVS}$ operation of control switch during turn-off. The large capacitance is required to hold the switch voltage closed to zero during current fall time of the switch $\left(t_{f_{i}}\right)$. The value of $t_{f i}$ can be taken from the data sheet. The value of $\mathrm{C}_{\mathrm{r} 1}$ can be calculated as,

$$
\mathrm{C}_{\mathrm{r} 2}=\frac{\mathrm{t}_{\mathrm{fi}} * \mathrm{I}_{s}}{\mathrm{~V}_{\mathrm{o}}}
$$

The resonant capacitor $\mathrm{C}_{\mathrm{r} 2}\left(=\mathrm{C}_{5}=\mathrm{C}_{6}\right)$ must be selected in such a way that the minimum requirement for $\mathrm{ZVS}$ operation of control switch during turn-off. The large capacitance is required to hold the switch voltage closed to zero during current fall time of the switch $\left(t_{f i}\right)$. The value of $\mathrm{C}_{\mathrm{r} 2}$ can be calculated as,

$$
\mathrm{C}_{\mathrm{r} 2}=\frac{\mathrm{t}_{\mathrm{fi}} * \mathrm{I}_{\mathrm{s}}}{\mathrm{V}_{\mathrm{O}}}
$$

The dc output filter elements are designed based on the following equations:

$$
\begin{gathered}
\Delta \mathrm{I}_{\mathrm{O}}=\frac{\mathrm{v}_{\mathrm{O}} *(1-\mathrm{k}) * \mathrm{~T}_{\mathrm{s}}}{\mathrm{L}_{\mathrm{f}}} \\
\frac{\Delta \mathrm{v}_{\mathrm{O}}}{\mathrm{v}_{\mathrm{O}}}=\frac{\pi^{2} *(1-\mathrm{k}) * f_{r}^{2}}{f_{s w}^{2}} \\
\mathrm{f}_{\mathrm{r}}=\frac{1}{2 * \pi * \sqrt{\mathrm{L}_{\mathrm{f}} * \mathrm{C}_{\mathrm{f}}}}
\end{gathered}
$$

Where $\Delta \mathrm{V}_{\mathrm{O}} \& \Delta \mathrm{I}_{\mathrm{O}}$ are the acceptable ripple contents in the dc output voltage and current waveforms, $V_{O}$ is the required $\mathrm{dc}$ output voltage, $\mathrm{f}_{\mathrm{r}}$ is the resonant frequency, $\mathrm{f}_{\mathrm{sw}}=\left(1 / \mathrm{T}_{\mathrm{s}}\right)$ is the switching frequency and $\mathrm{k}$ is the duty cycle of switch.

\section{Results and Discussions:}

The parameters of the proposed converter circuit shown in figure 2.1, are given in table 2.1

Table 2.1: Converter parameters

\begin{tabular}{|l|l|}
\hline Name of the parameter & Value \\
\hline Switching frequency, $\mathrm{f}_{\mathrm{sw}}$ & $10 \mathrm{KHz}$ \\
\hline DC Input voltage, $\mathrm{V}_{\mathrm{dc}}$ & $100 \mathrm{~V}$ \\
\hline DC Output voltage, $\mathrm{V}_{\mathrm{o}}$ & $24 \mathrm{~V}$ \\
\hline Parasitic capacitor, $\mathrm{C}_{\mathrm{r}}$ & $0.01 \mathrm{PF}$ \\
\hline Leakage Inductance of transformer, $\mathrm{L}_{\mathrm{lk}}$ & $4.86 \mathrm{uH}$ \\
\hline Magnetizing Inductance of transformer, $\mathrm{L}_{\mathrm{m}}$ & $3.97 \mathrm{H}$ \\
\hline
\end{tabular}




\begin{tabular}{|l|l|}
\hline Turns ratio of transformer $\left(\mathrm{N}_{\mathrm{P}}: \mathrm{N}_{\mathrm{S}}\right), \mathrm{N}_{\mathrm{T}}$ & $4: 1$ \\
\hline DC filter inductance, $\mathrm{L}_{\mathrm{f}}$ & $65 \mathrm{mH}$ \\
\hline DC filter capacitance, $\mathrm{C}_{\mathrm{f}}$ & $50 \mathrm{uF}$ \\
\hline DC load current, $\mathrm{I}_{\mathrm{o}}$ & $40 \mathrm{~A}$ \\
\hline Power Rating, $\mathrm{P}$ & $1000 \mathrm{~W}$ \\
\hline
\end{tabular}

Figure 2.14 show the gate pulses of the proposed converter switches. Sufficient dead time $\left(t_{\text {dead }}\right)$ is created between the control switches $S_{1} \& S_{4}, S_{3} \& S_{2}$ and $S_{5} \& S_{6}$ to avoid the source short circuit problem. The dead time is calculated based on the following equation

$$
t_{\text {dead }}=C_{r} * \frac{V_{d c}}{I_{p 0, \min }}
$$

Figure 2.15 show the voltage and current waveforms of transformer primary. From the figure, it is observed that the primary current of transformer increases gradually due to presence of leakage inductance and magnetizing inductance of the transformer which causes increase of the range of ZVS condition for primary side converter switches. When the positive $\mathrm{V}_{\mathrm{dc}}$ appears across the primary of the transformer, the current which is passing through the primary is of $5 \mathrm{~A}$ magnitude. Similarly, when the negative $V_{d c}$ appears across the primary of the transformer, then the reversed current flows through the primary of the transformer which is of $5 \mathrm{~A}$ magnitude.
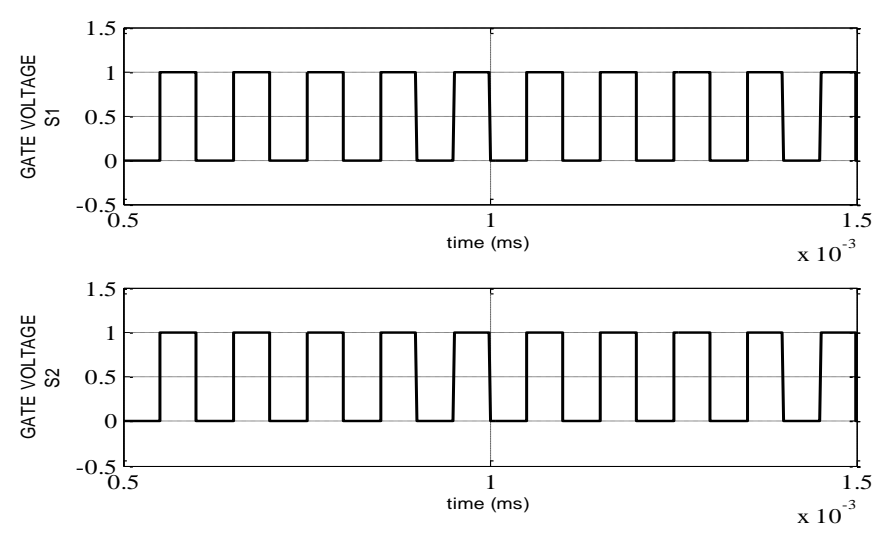

Figure 2.14 (a): Gate pulses for $S_{1}$ and $S_{2}$ switches
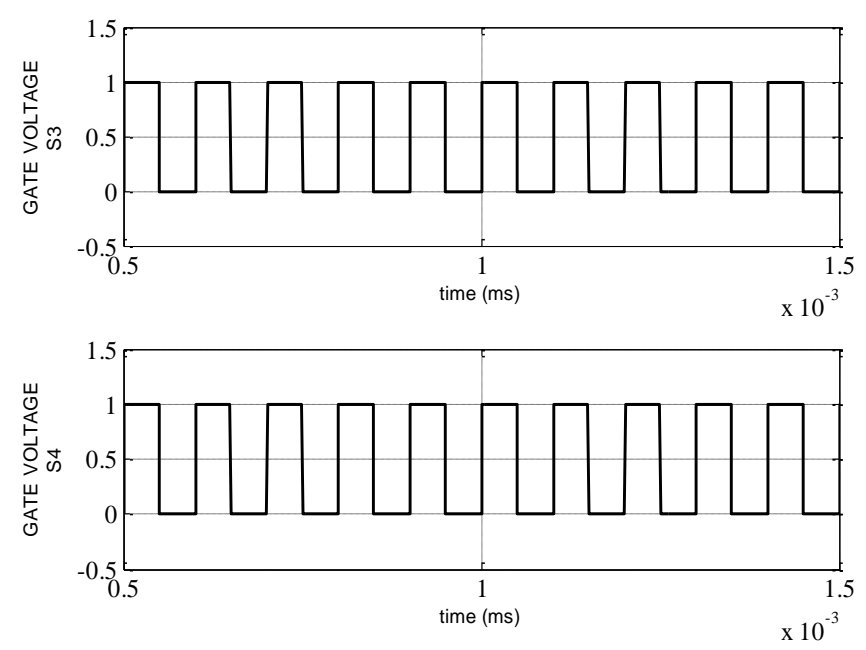

Figure 2.14 (b): Gate pulses for $S_{3}$ and $S_{4}$ switches
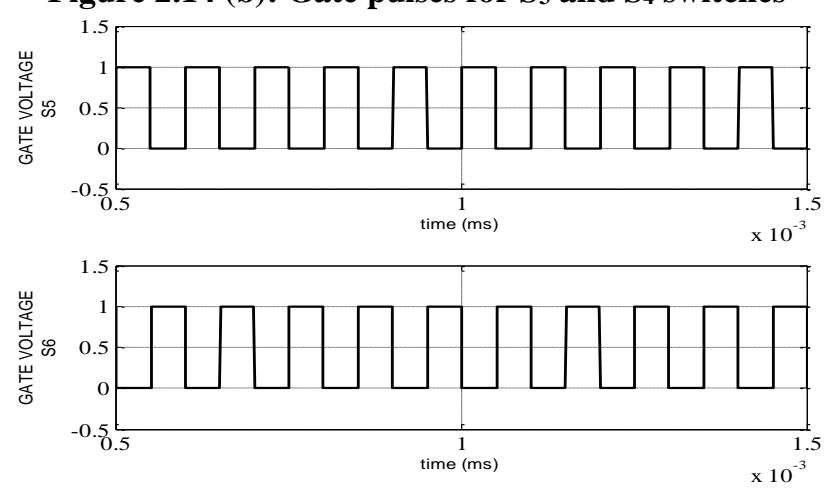

Figure 2.14 (c): Gate pulses for $S_{5}$ and $S_{6}$ switches Figure 2.14: Gate pulses for proposed converter switches
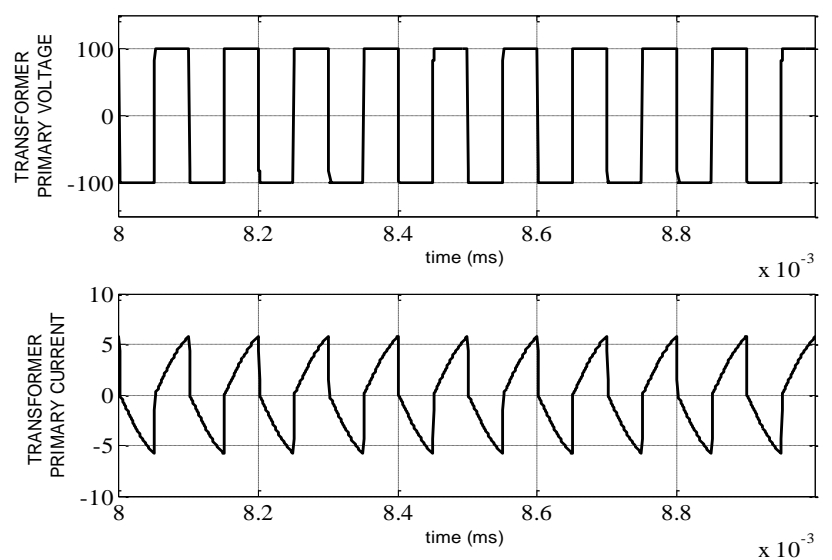

Figure 2.15 Transformer primary voltage and current waveforms 

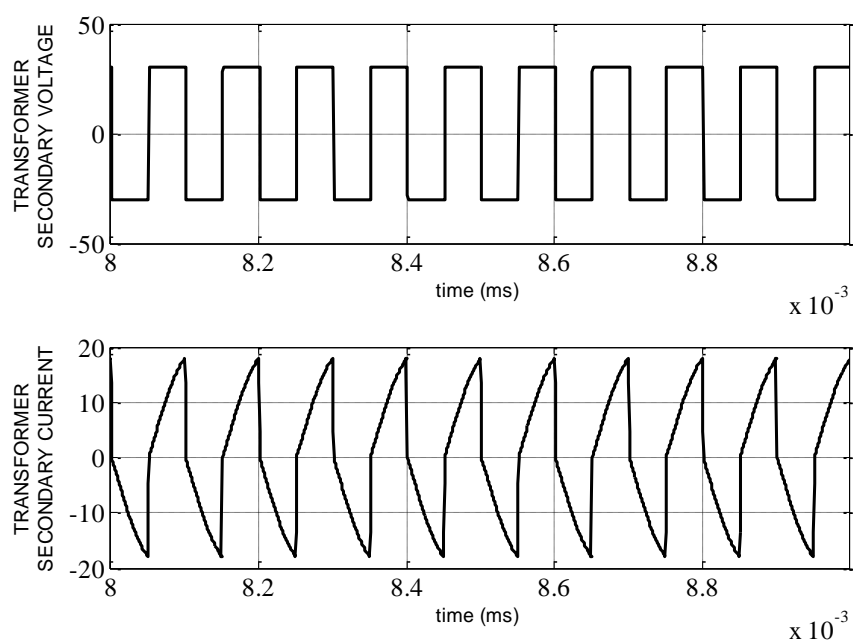

Figure 2.16: Transformer secondary voltage and current waveforms

Figure 2.16 show the voltage and current waveforms of transformer secondary. From the figure, it is observed that the secondary current of transformer increases gradually due to secondary leakage inductance of the transformer. When the positive $\mathrm{V}_{\mathrm{dc}} / 4$ appears across the secondary of the transformer, the current which is passing through the secondary is of $18 \mathrm{~A}$ magnitude and similarly the same thing happens for negative half cycle.

Figure 2.17 shows the dc output voltage waveform of the proposed converter with filter. The dc filter values are designed such a way that the ripple content present in $\mathrm{dc}$ output voltage and current waveform become less than $3 \%$. From the figure it is noticed that the dc output voltage is reached to its steady state value at time $\mathrm{t}=2.5 \mathrm{~ms}$.

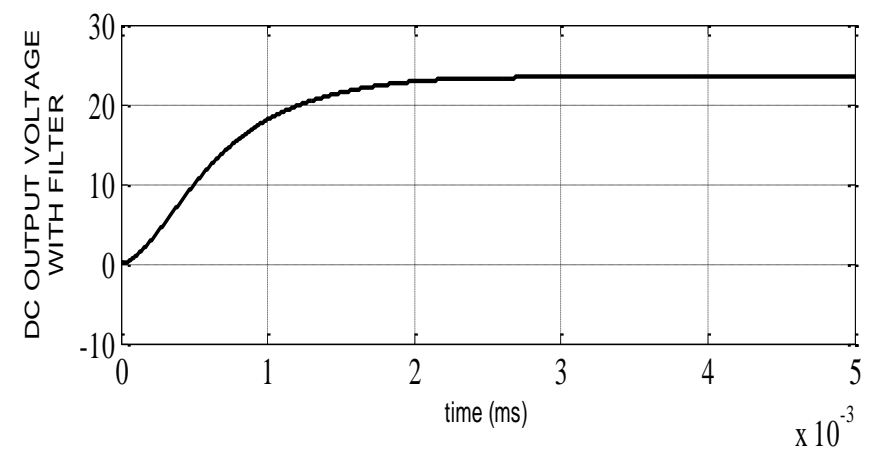

Figure 2.17: DC output voltage waveform with filter.

Figure 2.18 shows gate voltage, voltage across and current through switches $S_{1} \& S_{2}$ for the switching transition period from off state to on state. When the gate pulses are applied to $S_{1} \& S_{2}$, then the switches $S_{1} \& S_{2}$ are turned on and current passes through the switch from time $t=5.052 \mathrm{~ms}$, it is observed that the voltage across switch is still zero but current starts increasing, it indicates that the switching power loss is zero during transition period from off state to on state. That means ZVS is achieved for $S_{1} \& S_{2}$.
The ZVS is achieved across $S_{1} \& S_{2}$ due to clamping of the voltage to zero by the body diodes of $S_{1} \& S_{2}$. Hence, the switches $S_{1} \& S_{2}$ are turning on under ZVS during off to on transition period. The switches are completely turned on at time $\mathrm{t}=5.052 \mathrm{~ms}$, then the collector current of $\mathrm{S}_{1} \& \mathrm{~S}_{2}$ are starts rising from zero to $5 \mathrm{~A}$ and the collector to emitter voltage of $S_{1} \& S_{2}$ are decreased to zero due to their intrinsic capacitors $\mathrm{C}_{1} \& \mathrm{C}_{2}$

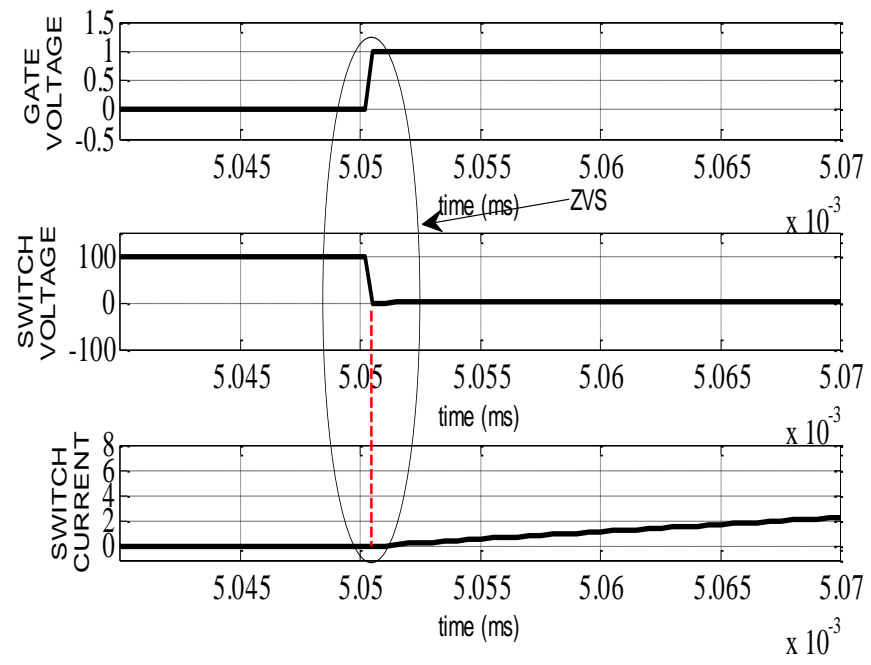

Figure 2.18: Gate voltage, voltage across and current through switches $S_{1} \& S_{2}$ during OFF to $O N$

Figure 2.19 shows the gate voltage, voltage across and current through switches $S_{1} \& S_{2}$ during on to off transition period. From figure 2.19, the turn on to turn off transition of switches $S_{1} \& S_{2}$ is occurred from the time $5.1 \mathrm{~ms}$ to $5.1005 \mathrm{~ms}$. The collector current of $S_{1} \& S_{2}$ starts falling from $5 \mathrm{~A}$ to zero in this interval, where as the collector-emitter voltages of $S_{1} \& S_{2}$ are clamped to zero due to their intrinsic capacitors $C_{1} \& C_{2}$. Therefore, the switches $S_{1} \& S_{2}$ are operate under ZVS during on to off transition instant and no switching power losses in this instant.

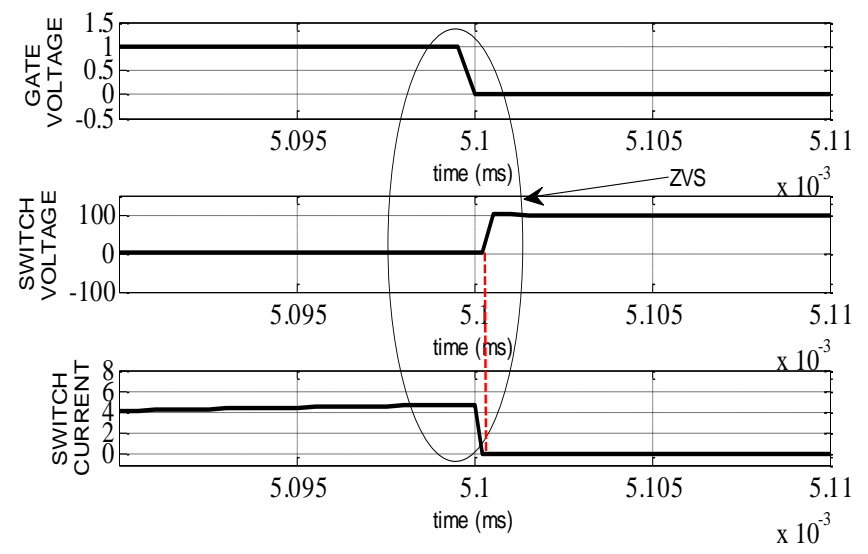

Figure 2.19: Gate voltage, voltage across and current through switches $S_{1} \& S_{2}$ during $O N$ to $O F F$ 
Figure 2.20 shows the gate voltage, voltage across and current through switches $\mathrm{S}_{3} \& \mathrm{~S}_{4}$ during off to on transition instant. The switches $\mathrm{S}_{3} \& \mathrm{~S}_{4}$ have been achieved zero -voltage turn-on, since the voltage is reduced to zero before the device is switched, as shown in Figure 2.20. The ZVS of switches $\mathrm{S}_{3} \& \mathrm{~S}_{4}$ during turn-off is shown in Figure 2.21 , here, the ZVS turn-off is achieved since the voltage across the switches rises during turn-off and reached to zero before the device finishes turning off. Hence, zero switching power loss during on state to off state and off state to on state transition instants.

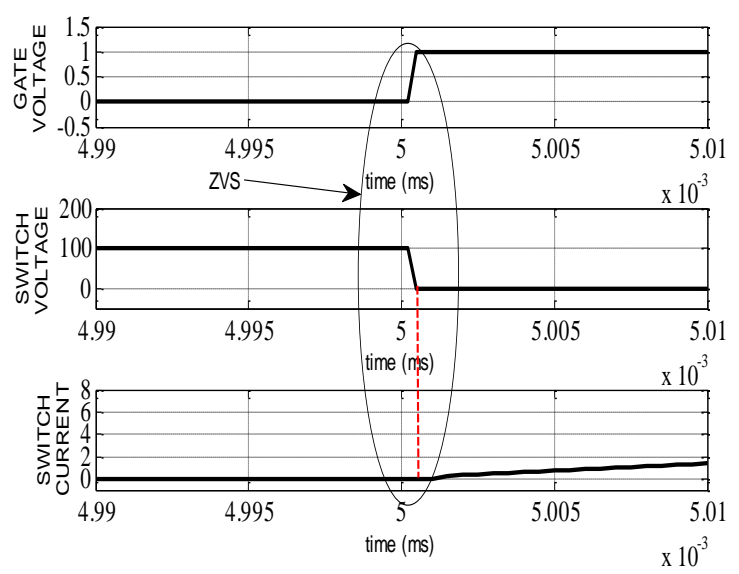

Figure 2.20: Gate voltage, voltage across and current through switches $S_{3} \& S_{4}$ during OFF to $O N$

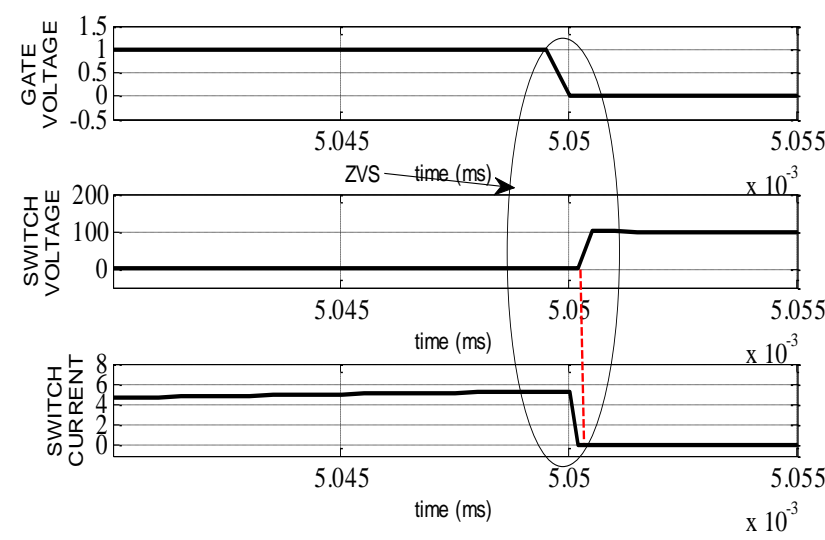

Figure 2.21: Gate voltage, voltage across and current through switches $S_{3} \& S_{4}$ during $O N$ to $O F F$

Figure 2.22 and 2.23 show the gate voltage, voltage across and current through switch $\mathrm{S}_{5}$ during turning off and turning on transition instants respectively. From figure 2.22, during turn on transition, the collector to emitter voltage of switch is reached to zero before collector current of switch rises from zero due to clamping of its body diode. Thus, it can be noticed that the switch $\mathrm{S}_{5}$ turns-on under ZVS mode. From Figure 2.23, during turn-off transition, the collector to emitter voltage of switch has reached to zero before collector current of switch falls to zero due to its intrinsic capacitor $\mathrm{C}_{5}$. Thus, it can be noticed that the switch $\mathrm{S}_{5}$ turns-off under ZVS mode.
Therefore, zero switching power loss during off state to on state and vice versa.

From figures 2.22 and 2.23 , it shows that the voltage stresses on the secondary side are clamped to the output voltage and the voltage spikes on the secondary side are suppressed due to soft switching. In addition, there is no reverse recovery current in the rectifier diodes, because the rate of current falling is controlled by the transformer leakage inductance. In the similar manner, the control switch $\mathrm{S}_{6}$ also operates under ZVS during switching transition period.

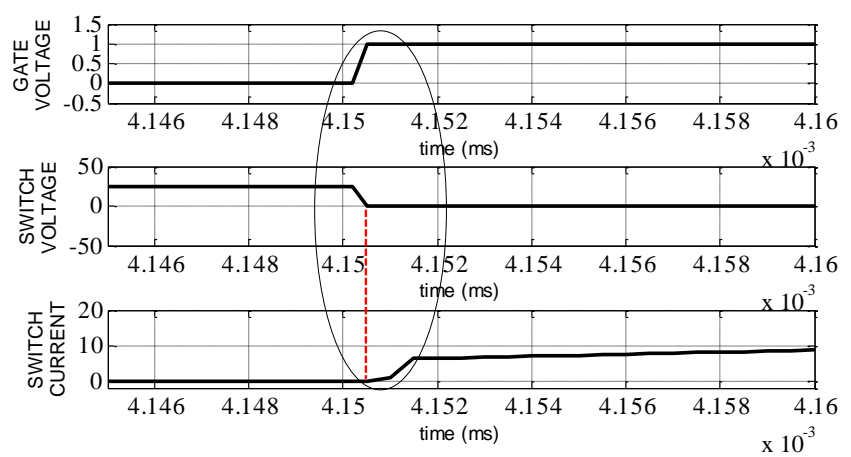

Figure 2.22: Gate voltage, voltage across and current through $\mathrm{S}_{5}$ during OFF to $\mathrm{ON}$

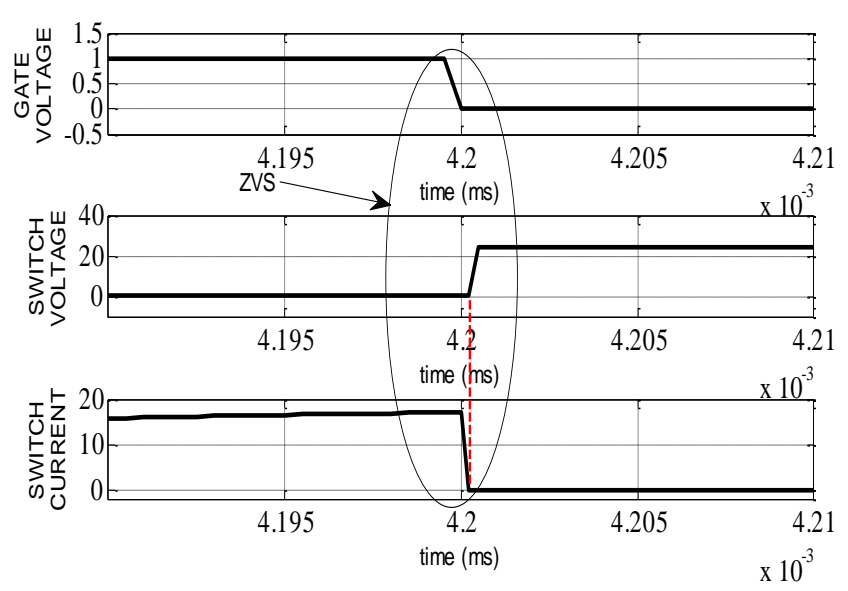

Figure 2.23: Gate voltage, voltage across and current through $\mathrm{S}_{5}$ during $\mathrm{ON}$ to $\mathrm{OFF}$

Table 2.2: Comparison of efficiencies of proposed converter for various load currents

\begin{tabular}{|c|c|c|c|c|}
\hline S.NO & $\begin{array}{c}\text { LOAD } \\
\text { CURRENT } \\
\text { (Amps) }\end{array}$ & $\begin{array}{c}\text { OUTPUT } \\
\text { POWER } \\
\text { (Watts) }\end{array}$ & $\begin{array}{c}\text { INPUT } \\
\text { POWER } \\
\text { (Watts) }\end{array}$ & $\begin{array}{c}\text { EFFICIENCY } \\
(\%)\end{array}$ \\
\hline 1 & 6 & 159.1 & 186.1 & 85.5 \\
\hline 2 & 12 & 299.4 & 335.7 & 89.18 \\
\hline 3 & 16 & 424 & 472 & 89.86 \\
\hline 4 & 22 & 541.1 & 602.3 & 89.85 \\
\hline 5 & 31 & 763 & 884.9 & 86.26 \\
\hline 6 & 34 & 814.8 & 958 & 85.05 \\
\hline 7 & 38 & 902.7 & 1087 & 83.04 \\
\hline 8 & 40 & 951.7 & 1174 & 81.09 \\
\hline
\end{tabular}


Table 2.2 shows the $\%$ efficiency of the proposed single input single output two level DC-DC converter with SPS for different load currents. Table 2.3 shows the \% efficiency of proposed two level DC-DC converter with existing two level DC-DC converter [11] for various load currents. The performance of proposed two-level DC-DC converter is compared with the existing two-level DC-DC converter with same parameters as specified in table 2.1 in order to validate the proposed work. It is clear that the efficiency of proposed two-level SPS DC-DC converter is higher than the existing two-level DC-DC converter [11].

Table 2.3: Comparison of efficiency of proposed converter with existing converter for various load currents

\begin{tabular}{|c|c|c|c|}
\hline S.NO & $\begin{array}{c}\text { Load } \\
\text { Current } \\
\text { (Amps) }\end{array}$ & $\begin{array}{c}\text { Proposed } \\
\text { Two-level } \\
\text { SPS DC-DC } \\
\text { Converter }\end{array}$ & $\begin{array}{c}\text { Existing two- } \\
\text { level DC-DC } \\
\text { converter } \\
{[11]}\end{array}$ \\
\hline 1 & 6 & 85.5 & 81.2 \\
\hline 2 & 12 & 89.18 & 84.9 \\
\hline 3 & 16 & 89.86 & 85.8 \\
\hline 4 & 22 & 89.85 & 86.2 \\
\hline 5 & 31 & 86.26 & 85.3 \\
\hline 6 & 34 & 85.05 & 83.9 \\
\hline
\end{tabular}

\section{Conclusion}

In this paper, soft switching control strategy for single input single output two-level isolated DC-DC converter with secondary side phase shifting (SPS) was developed. The proposed converter with SPS was provided wider soft switching range and reduced power loss due to reduction of circulating current in the primary side of high frequency transformer. In addition, the proposed scheme provide no reverse recovery current in diodes and hence no power losses in the secondary side rectifier circuit. The efficiency of the proposed two-level DC-DC SPS converter was compared with existing two-level DC-DC converter for validating the proposed work. From the comparison, it was noticed that the efficiency of the proposed DC-DC converter with SPS is higher than the existing two-level DC-DC converter.

\section{References}

[1] A.J.Mason, D.J.Tschirhart, and P.K.Jain, "New ZVS phase shift modulated full bridge converter topologies with adaptive energy storage for SOFC application," IEEE Trans. Power Electron., Vol. 23, no. 1, pp. 332342, Jan. 2008.

[2] J.-G. Cho, J.-W. Baek, C.-Y. Jeong, D.-W. Yoo, and K.-Y. Joe, "Novel zero-Voltage and zero-currentswitching full bridge PWM converter using transformer auxiliary winding," IEEE Trans. Power Electron., Vol. 15, no. 2, pp. 250-257, Mar. 2000.

[3] H.Cha, L.Chen, R.Ding, Q.Tang and F.Z.Peng, "An alternative energy recovery clamp circuit for full bridge PWM converters with wide ranges of input Voltage," IEEE Trans. Ind. Electron., Vol. 23, no. 6, pp. 28282837, Nov, 2008.

[4] Y.Jang and M.MJovanovic, "A new PWM ZVS fullbridge converter," IEEE Trans. Power Electron., Vol. 22, no. 3, pp. 987-994, May 2007.

[5] P. K. Jain, W. Kang, H. Soin, and Y. Xi, "Analysis and design considerations of a load and line independent zero Voltage switching full-bridge DC/DC converter topology," IEEE Trans. Power Electron., Vol. 17, no. 5, pp. 649-657, Sep. 2002.

[6] X. Wu, X. Xie, C. Zhao, Z. Qian, and R. Zhao, "Low Voltage and current stress ZVZCS full bridge dc-dc converter using center tapped rectifier reset," IEEE Trans. Ind. Electron., Vol. 55, no. 3, pp. 1470-1477, Mar. 2008.

[7] W. J. Lee, C. E. Kim, G.W. Moon, and S. K. Han, "A new phase-shift full bridge converter with Voltagedoubler-type rectifier for high-efficiency PDP sustaining power module," IEEE Trans. Ind. Electron., Vol. 55, no. 6, pp. 2450-2458, Jun. 2008.

[8] S. Moissev, K. Konishi, S. Sato, L. Gamage, and M. Nakaoka, "Novel soft-commutation dc-dc power converter with high frequency transformer secondary side phase-shifted PWM active rectifier," IEE Proc. Electric Power Appl., Vol. 151, no. 3, May 2004.

[9] X. Zhang, W. Chen, X. Ruan, and K. Yao, "A novel ZVS PWM phase shifted full-bridge converter with controlled auxiliary circuit," in Proc. IEEE Applied Power Electron. Conf., Feb. 2009, pp. 1067-1072.

[10] H. Hamada and M. Nakaoka, "Analysis and design of a saturable reactor assisted soft-switching full-bridge dcdc converter," IEEE Trans. Power Electron., Vol. 9, no. 3, pp. 309-317, May 1994.

[11] J. Zhang, F. Zhang, X. Xie, D. Jiao, and Z. Qian, "A novel ZVS dc-dc converter for high power applications," IEEE Trans. Power Electron., Vol. 19, no. 2, pp. 420-429, Mar. 2004.

[12] T. Mishima and M. Nakaoka, "Practical evaluations of A ZVS-PWM DC-DC converter with secondary-side phase-shifting active rectifier," IEEE Trans. Power Electron., Vol. 57, no. 99, pp. 1-12, Oct. 2011.

[13] C. Yao, X. Ruan, X. Wang, and C. K. Tse, "Isolated buck-boost DC/DC converters suitable for wide inputVoltage range," IEEE Trans. Power Electron., Vol. 26, no. 9, pp. 2599-2613, Sep. 2011.

[14] M. A. Sayed, K. Suzuki, T. Takeshita, andW. Kitagawa, "PWM switching technique for three-phase bidirectional grid-tie dc-ac-ac converter with highfrequency isolation," IEEE Trans. Power Electron. vol. PP, no. 99, pp. 1-1, 2017. 